Orissa Journal of Commerce

Vol. 42, Issue 3, July-September 2021

ISSN: 0974-8482

(C) OJC India. All Right Reserved

URL: www.ojcoca.org

DOI: https://doi.org/10.54063/ojc.2021.v42i03.02

\title{
A Study of India's Trade Flows with the ASEAN: Gravity Model Analysis
}

\author{
Saurabh Kumar Bharti ${ }^{1^{*}}$ and Syeedun Nisa ${ }^{2}$ \\ ${ }^{1}$ Junior Research Fellow, Department of Management, School of Management and Business Studies, Jamia Hamdard, New Delbi. \\ E-mail: saurabhshyamal23@gmail.com \\ ${ }^{2}$ Assistant Professor, Department of Management, School of Management and Business Studies, Jamia Hamdard, New Delhi. \\ E-mail:syeedunnisa.warsi@gmail.com \\ ${ }^{*}$ Corresponding Author
}

To cite this paper

Bharti, S.K., \& Nisa, S. (2021). A Study of India's Trade Flows with the ASEAN: Gravity Model

Analysis. Orissa Journal of Commerce. 42(3), 15-26.

Keywords

ASEAN, India, FTA, Gravity model, International business

JEL Classification B27, C01, C33, F53, O53

\begin{abstract}
This research aims to see how the Association of Southeast Asian Nations Free Trade Agreement (ASEAN FTA) affects the merchandise trade of India. As a research approach, this work employed the gravity model with panel data estimation. The data has been derived from 27 trade partner nations with three key economic blocs for the period 2011 to 2020. Under diagnostic testing, panel data regression was estimated with Ordinary Least Square (OLS), fixed effects and random effect models. The white test applied for heteroskedasticity bias encountered as usual in the OLS method. The random effect model significantly outperforms the fixed effect model in the Hausman Specification test. The result of the Generalized Least Squares (GLS) Random Effect revealed that India's Gross Domestic Product (GDP) and the GDP of destination countries have a significant impact on overall trade, whereas geographical distance, common official language, common border, landlocked variables show an insignificant result. ASEAN-India FTA (AIFTA) has negative coefficients and an insignificant impact on India's trade.
\end{abstract}

\section{Introduction}

Until 1991, the Indian economy was hampered by high tariffs and duties. Major trade liberalization measures had undertaken post-1991 marked a considerable break from past year's protective trade policies. The degree of protection provided to the Indian economy has dropped substantially owing to the government's broad liberalization and globalization strategy, which has led to significant tariff reductions and the abolition of quantitative limitations (Panagariya, 2004). Furthermore, when India joined the WTO as a founding member in 1995, it became a legal requirement to abolish all quantitative limits on imports, cut import tariffs, open up the markets to international business and begin the globalization process. India has emphasized the need of coordinating trade policies to streamline procedures, increase transparency, and eliminate arbitrariness. The risk and protective factors in the foreign market are determined 
by this process, which assesses the continual evolution of economic policies, the formation of new market circumstances, and the establishment of both formal and informal mechanisms.

Regional trade agreements (RTAs) are viewed as stepping stones towards India's larger objective of economic integration. It has entered into various RTAs, notably preferential trade agreements (PTAs), FTAs, and other economic arrangements (ASEAN, 2012). RTAs could help to boost liberalization by acting as building blocks at the multilateral level of integration. RTAs have also been found to trigger foreign direct investments (Ando \& Kimura 2005) and augment trade liberalization in services as compared to the General Agreement on Trade and service (GATS) commitments. Thus, RTAs have been considered to be a step on the path for a more globalized world. Moreover, RTA has also been widely panned for a variety of reasons. RTAs, according to Viner (1950) may lead to significant welfare losses in both member and non-member nations. RTAs can cause an unsustainable spaghetti bowl effect and are typically biased against developing nations by lowering their negotiating power in comparison to rich countries (Krueger \& Bhagwati 1995). Many economists, including Limao (2006) and Bhagwati (2008) are concerned that RTAs may jeopardize the multilateral trading system.

India initiated its Look East Policy in 1991, which aims to strengthen economic and geopolitical ties with Southeast Asian nations. By seeking FTA with ASEAN, India is moving out of a solely multilateral strategy. According to Bhagwati (2003), India has certainly started a regional barrage, justifying its curious choice of ASEAN as its major preferential trading partner. Given her profound historical, cultural and maritime links with Southeast Asian states and the territories outside it, India is no stranger to them (Acharya, 2017). From regional key stakeholders to decisive allies, ASEAN and India have cooperated since 1992. India became a major associate partner of the ASEAN Regional Forum (ARF) in 1997 and elevated to summit level ally in 2002. ASEAN and India had ratified the Comprehensive Economic Cooperation Agreement (CECA) in 2003, culminating in the creation of a Regional Trade and Investment Partnership (RTIP). After six years of talks, the ASEAN - India Free Trade Area (AIFTA) had been ratified on August 13, 2009, in Bangkok recognizing the market prospects of direct trade. On January 1, 2010, the AIFTA became operational. India's connection with the ASEAN has gotten stronger over time. Since 2014, New Delhi has been bolstering its ties with ASEAN.

Act East is a governmental endeavour aimed at strengthening economic, geopolitical and cultural ties with Asia. "Look East" and its successor, "Act East" are not opposed; instead they denote two separate but concurrent periods in India's Asia-Pacific policy. The policy is supplemented by the New Southern Policy of South Korea, along with the Free and Open Indo-Pacific strategy of Japan. These countries realized the significance of ASEAN, along with their economic and geopolitical objectives within Indo-Pacific and formed a cooperative synergy (Dinakaran, 2020). Each of these developments, together with the utmost efforts of hard-pressed diplomats to maintain strong government-togovernment (G2G) ties, have boosted India-ASEAN business-to-business (B2B) and people-to-people (P2P) interaction. Various studies have been conducted to assess the effect of the India- ASEAN FTA. ASEAN will reap the majority of the short-term gains (Dasgupta and Pal, 2009). Plantation product's imports increased from India through the establishment of trade channels (Veeramani, 2010). However, according to Nag and Sikdar (2011), India's trade will grow as a result of the ASEAN's bigger trading partners. On the other end, allocative inefficiency may result in deteriorating welfare in 
India. Bhattacharyya and Mandal (2010) found that most tradable items have minimal tariff elasticity, which means that tariff adjustments can only cause proportional changes in trade. Using the GTAP model, Ahmad (2010) finds that in terms of GDP, both India and ASEAN benefited, while India's trading prospects deteriorate.

In 2008-09, India's bilateral trade with ASEAN was over 45 billion US dollars, which stands for nine per cent of India's entire foreign trade (Tewari and Das 2010). India's overall goods exports to ASEAN continuously rose at a compound annual growth rate by around five per cent from 23 billion US dollars in 2011 to 36 billion US dollars in 2018, whereas the imports of goods from the tenmember bloc grew by around eight per cent from 30 billion US dollars in 2011 to 57 billion US dollars in 2018. During the fiscal year 2019-20, India's exports to ASEAN amounted to 31.55 billion US dollars whilst the imports from the region reached 55.37 billion US dollars (Kapur, 2021).

Table 1: India-ASEAN Trade Data for 2015 to 2020 (April-March)

\begin{tabular}{lrrrrr}
\hline India's trade with ASEAN & $2015-16$ & $2016-17$ & $2017-18$ & $2018-19$ & $2019-2020$ \\
\hline EXPORT (Billion USD) & 25.13 & 30.96 & 34.20 & 37.47 & 31.55 \\
\% Growth & -21.00 & 23.19 & 10.47 & 9.56 & -15.82 \\
IMPORT (Billion USD) & 39.91 & 40.62 & 47.13 & 59.32 & 55.37 \\
\% Growth & -10.75 & 1.77 & 16.04 & 25.86 & -6.66 \\
TOTAL (Billion USD) & 65.04 & 71.58 & 81.34 & 96.80 & 86.92 \\
Trade Balance (Billion USD) & -14.78 & -9.66 & -12.93 & -21.85 & -23.82 \\
\hline
\end{tabular}

Source: Foreign Trade Territorial Division, Ministry of Commerce and Industry, Government of India.

\section{Review of Literature}

In pragmatic studies of international business, the gravity framework has been frequently applied to assess cross-national trade flows. This model is often referred to as a workhorse in the econometric model. Dutch economist Tinbergen (1962) initially applied the model to evaluate international trade patterns. However, Anderson (1979) was the one who originally presented the theoretical underpinning for this gravity model. Bergstand (1985), went ahead by segregating the roles of GDP and per capita GDP before formulating the gravity equation. Following Tinbergen's pioneering study, a slew of other experts subsequently used the gravity equation to achieve similar goals.

The gravity framework has been often used to explain bilateral trade and investments in foreign trade studies (Zwinkels and Beugelsdijk 2010). They had applied the equation to assess the efficiency of Mercosur-EU exports after the two trade blocs reached an agreement (Martiinez-Zarzoso et al., 2009). When they applied to the classic gravity model, their findings reveal that numerous factors such as infrastructure, GDP and currency rates are major determinants of foreign trade. Rahman (2003), examine data from 50 nations incorporating augmented gravity equation and shows that economic size, GDP, language, openness all have a significant effect on Australia's foreign trade. The geographical distance between partner countries has a negative impact. Furthermore, Chan (2005) examined trade flows in Korea, Bhattacharya (2006) explained trade patterns in India, studied whether the gravity 
model can explain African exporting activities. Endoh (1999), revealed that the ASEAN had a favourable and substantial impact on trade flows, whereas, factors was negative and insignificant in two estimations. The gravity model is an effective method for examining free trade (Egger and Pfaffermayr 2005), the impact of currency integration on international trade (Rose, 2004), service trade (Kimura, 2005), business to business trade and Foreign Direct Investment (Egger and Pfaffermayr, 2005).

In general, the traditional gravity framework had been empiric in determining the effect of gross domestic product, bilateral distance and various dummy factors like common official language, colonial connections, contiguous borders, and RTA on cross border trade. However, the conventional gravity framework has been criticized for producing biased observations of the determinants of international trade flows as it fails to control multilateral resistance terms (MTRs). To address these unobservable MTRs, it is a common procedure in the literature to integrate exporter and importer fixed effects in the gravity specification (Yotov et al., 2016). Based on these considerations, this study will seek to discuss the fundamental concern for fostering regional trade agreements.

Brulhart and Kelly (1999), are among the pragmatic researchers who employed cross-section data in the gravity equation. Due to its illustrative nature, the priority switched from cross-section to multidimensional data (panel or longitudinal data). Many researchers employed panel data structure for their study e.g., Rose and van Wincoop (2001). Longitudinal data as opposed to time series is more revealing (less collinearity) and allows for a large extent of liberty. Individual heterogeneity that goes unobserved can also be managed using longitudinal data (Bruderl, 2005). As reported by Gomez and Baleix (2012), the outcome from panel data might vary significantly bank on the group chosen, resulting in estimate bias. Due to the incapacity to cope with bilateral heterogeneity, the cross-section estimation findings are mis-specified, it will certainly be present in international trade (Shin and Serlenga, 2007). In such instances, the best strategies to cope with heterogeneity problems is to use a panel data structure, with time and country-specific dummy variables. Matyas (1997), further suggested that the accurate econometric formulation of gravity equation includes time, exporter and importer fixed effects in the study. There are different types of models for estimating the panel data regression. The random effect approach is preferable to the fixed effect if the impetus of the analysis is to assess both timevariant and time-invariant factors on trade between nations (Ozdeser and Ertac, 2010).

\section{Objectives of the Study}

The main objectives of the study are:

- To examine the determinants of India's trade flows with ASEAN.

- To estimate the effects of regional trade agreement using gravity framework.

- To identify the scope of trade between India and ASEAN.

\section{Research Methodology}

\subsection{Data Sources}

The Direction of Trade Statistics (DOTS) provided the bilateral trade statistics for the period 2011-2020 (in US dollars), (IMF, 2021). The IMF's World Economic Outlook database has been used to obtain 
GDP statistics. The distance (great circle distance formula), border, language, and common colony data are from the Centre for Prospective Studies and International Information (CEPII-Database, 2021).

\subsection{Statistical Model}

The following is a multiplicative version of the fundamental Gravity Model:

$$
X i j t=Y i Y j / \text { Distanceij }
$$

Where $X i j t$ denotes the economic value of bilateral trade (export and import) between country $i$ and $j$, and $Y i$ and $Y j$ are the respective incomes (GDP per capita). The geographical distance allying countries $i$ and $j$ is represented by Distanceij. It asserts that the reciprocal trade between nations $i$ and $j$ is corresponding to their respective GDP (income) and is inversely proportional to geographical distance. Only the GDP and distance factors were incorporated in the traditional Gravity equation, but in the standard Gravity, other variables such as shared border, common official language and per capita income are added in addition to these two variables (Frankel, 1997).

The fundamental gravity equation is modified in this work, with our estimating equation in natural logs presented below:

LnTradeijt $=\beta 0+\beta 1$ LnGDPit $+\beta 2$ LnGDPjt $+\beta 3$ LnDistanceij $+\beta 4$ Common Borderij $+\beta 5$ Common Languageij $+\beta 6$ Colonial Linkij $+\beta 7$ Landlocked $+\beta 8$ AIFT $A+\beta 9$ BIMSTEC + cijt

Table 2: Variable Description and Signs/Hypotheses

\begin{tabular}{|c|c|c|}
\hline Variables & Descriptions & $\begin{array}{l}\text { Expected } \\
\text { Sign/Hypothesis }\end{array}$ \\
\hline \multicolumn{3}{|c|}{ Dependent Variable } \\
\hline Ln'Trade $\ddot{j t}$ & $\begin{array}{l}\text { Natural log of total trade between country } i \text { and } j \\
\text { for a year }\end{array}$ & \\
\hline \multicolumn{3}{|c|}{ Independent Variables } \\
\hline LnGDPit & Natural log of GDP of reporter country $i$ in time $t$ & + \\
\hline LnGDPjt & Natural log of GDP of trade partner country $j$ in time $t$ & + \\
\hline LnDistance $\ddot{y j}$ & Natural log of geographical distance between country $i$ and $j$ & - \\
\hline Common Border $\ddot{j}$ & $\begin{array}{l}\text { Binary value } 1 \text { if countries } i \text { and } j \text { share a common border } \\
\text { and } 0 \text { otherwise. }\end{array}$ & + \\
\hline Common Language $\ddot{j}$ & $\begin{array}{l}\text { Binary value } 1 \text { if countries } i \text { and } j \text { share common official } \\
\text { language and } 0 \text { otherwise. }\end{array}$ & + \\
\hline Colonial Link $i j$ & $\begin{array}{l}\text { Binary value } 1 \text { if both countries were under colonial rule and } \\
0 \text { otherwise. }\end{array}$ & + \\
\hline Landlocked & Binary value 1 if country is landlocked and 0 otherwise. & - \\
\hline AIFTA & $\begin{array}{l}\text { Binary value } 1 \text { if country representing common membership } \\
\text { to ASEAN FTA and } 0 \text { otherwise. }\end{array}$ & + \\
\hline BIMSTEC & $\begin{array}{l}\text { Binary value } 1 \text { if country representing common membership } \\
\text { to BIMSTEC and } 0 \text { otherwise. }\end{array}$ & + \\
\hline Eijt & Error term & \\
\hline
\end{tabular}


The growth of GDP of the reporting nation (i) induces greater output, which raises the supply of goods for trade. Thus, we can anticipate the reporter country's GDP to have a positive coefficient sign. The partner country's high GDP indicates more purchasing power. As a result, the GDP of the partner nation has a positive coefficient sign.

Since the distance variable is a surrogate for potential trading resistance elements, the computed coefficient sign of distance should be negative. The geographical closeness of any two countries will have a favourable influence on trade flows. The common border factor is used to reflect geographic closeness. Trade partners who share a border are more likely to trade than those who are far apart. This will reduce the cost of trading with one another. Furthermore, the coefficient of the common border variable should be positive.

Cultural link between nations is another major factor impacting trade flows. Members will be more culturally familiar if they have a common official language. As a result of the cultural connection, transaction cost among countries will be reduced. The common official language dummy variable captures the cultural link. The shared language and colonial connection factor are predicted to have a positive estimated coefficient as well.

Landlocked nations are particularly sensitive to border transit times; each additional day diminishes exports. It is projected that the landlocked variable would have a detrimental influence on commerce.

AIFTA and the Bay of Bengal Initiative for Multi-Sectoral Technical and Economic Cooperation (BIMSTEC) are added as dummy variables in the research study. The positive and significance of regional dummy variables indicate that multilateral trade agreements tend to increase trade more than bilateral trade agreements.

\section{Results and Discussion}

For the study, a panel of data on total commodities exchanged between India and 26 Asian nations was compiled during a 10-year period (2011-2020). The two most prevalent issues with panel data are autocorrelation and heteroscedasticity. As a result, the White test (1980) was used to determine heteroscedasticity. It examines the notion of homoscedasticity, which asserts that the error term's variances are constant across units. The outcome of the White test is statistically significant, with the p-value of 0.0000 , the assumption of homoscedasticity is rejected.

It is critical to use the best appropriate estimating approach to achieve consistent results. Distance, shared border, common language, colonial link, landlocked, AIFTA and BIMSTEC dummy variables are among the time-invariant factors in the research. There may be a link between these variables and the error term. The p-value for the Hausman Specification test was 0.2340, which is not statistically significant and indicates strong evidence for the null hypothesis. As a result, the present study used the random effect model rather than the fixed effect. The Random Effect model has the capability of removing heteroscedasticity from the equation (Bell et al., 2018). The $\mathrm{R}$ square 0.667 shows that the model got high explanatory power with a 66 per cent change in the total trade is elucidated by the independent factors outlined in the study. The p-value (Prob> chi $2=0.0000)$ is less than 0.05 , shows the model is statistically significant.

Given the number of independent factors, the distance between India and its trading partner had an unexpectedly positive and insignificant influence on overall trade, 0.166 points. It indicates that for 
every 1 per cent rise in the distance between partner nations, India's trade will grow by 0.166 per cent. The finding challenges the gravity framework, which states that distance influences the reciprocity between two bodies. The longer the distance between India and the target nation, the higher the transportation cost. Several studies, however, claim that the distance between the two nations has little impact on trade. One of its reason is that technology improvement can lower transportation costs sustainably. Goods which transported has become inexpensive and rapid in a sustainable manner as technology advances. Technical advances have been counterbalanced by major changes in vessel input and operational expenses, resulting in lower shipping costs (Hummels, 2007).

The findings of this analysis demonstrate that India's fluctuating gross domestic product (GDP) has negative and substantial effects on total trade, totaling -0.376 points in 26 Asian nations between 2011 and 2020. The GDP of partner nations, on the other hand, has favourable and substantial results. It indicates that for every $1 \%$ rise in GDP, total trade will increase by 0.95 per cent. The negative connection between India's GDP and total trade contradicts the gravity theory. The majority of tradable commodities of India are low-tech items such as leather footwear, jewels, marine products, organic chemicals, cereals, fruit and so forth. These goods are distinctive items with a close substitute readily available. Price sensitivity is likely to be a factor in such product demand. A country with a cheaper price can sell more than its competitors. In contrast, the ASEAN countries have higher export to GDP ratio and this agreement provided them with better access to Indian markets. The AIFTA does not help India's Small and Medium Enterprises (SMEs) but it does benefit nations like Thailand, Indonesia and Malaysia (Francis, 2011).

The coefficient of common official language is negative that has had no significant influence on trade. While the colonial link was found to have a favourable influence on bilateral trade. The common border coefficients reveal that it has a negative and insignificant impact on the bilateral trade that supports the findings of a previous work by Gul and Yasin (2010), which revealed that a shared border is not required for greater trade between the two nations. Myanmar and India share a 1643 kilometre border in the country's North-Eastern region. Border trade is abysmal, owing to insufficient infrastructure, difficult terrain, and an insecure commercial environment as described in the previous research (Routray, 2011). As per Majumdar and De (2014), the overall trade between Myanmar and India is hard to assess since trade is routed through a third nation like Singapore, and trade data is limited.

The coefficient of the landlocked variable shows a positive and insignificant effect on trade. Lao PDR, Afghanistan, Nepal and Bhutan are landlocked trade partners in the data set. Due to poor domestic industries, these country's bargaining power is severely constrained. Nepal and Bhutan are landlocked countries whose access to the ocean for trade objectives is reliant on India.

The membership of the ASEAN FTA shows a negative and insignificant bearing on India's trade. From the perspective of India, the original goal and motive for entering AIFTA, which was to enhance commerce, has not been realized. It is seen in the coefficient of the AIFTA variable which shows negative with the value of -0.200446 points, and not significant. Many studies affirm that India's FTA allies will gain more than India itself. As part of the agreement, India has had made significant tariff reduction commitments thus raising the apprehension that the deal might be favouring ASEAN more than India (Pal and Dasgupta, 2009). So many traversing FTAs could allow nations to pursue discriminatory trade practices, and limit trade advantages (Bhagwati, 2003). The regression coefficients 
of BIMSTEC is positive but statistically insignificant. According to the results of this study, the BIMSTEC possesses several features that make it a good potential for a free trade agreement.

Table 3: Estimation Results of Gravity Model

\begin{tabular}{|c|c|c|c|}
\hline Independent Variables & $\begin{array}{c}\text { (1) } \\
\text { Pooled OLS }\end{array}$ & $\begin{array}{c}\text { (2) } \\
\text { Fixed Effect }\end{array}$ & $\begin{array}{c}\text { (3) } \\
\text { GLS Random Effect }\end{array}$ \\
\hline LnDISTANCEij & $\begin{array}{l}.47^{* *} \\
(.213)\end{array}$ & - & $\begin{array}{l}.166 \\
(.762)\end{array}$ \\
\hline LnGDPit & $\begin{array}{l}-.232 \\
(.39)\end{array}$ & $\begin{array}{c}-.511 * * * \\
(.163)\end{array}$ & $\begin{array}{c}-.376^{* * * *} \\
(.142)\end{array}$ \\
\hline LnGDPjt & $\begin{array}{c}.734^{* * *} \\
(.048)\end{array}$ & $\begin{array}{c}1.15^{* * *} \\
(.171)\end{array}$ & $\begin{array}{c}.948^{* * *} \\
(.124)\end{array}$ \\
\hline Common Borderij & $\begin{array}{l}-.154 \\
(.237)\end{array}$ & - & $\begin{array}{l}-.514 \\
(.847)\end{array}$ \\
\hline Common Languageij & $\begin{array}{l}-.014 \\
(.246)\end{array}$ & - & $\begin{array}{c}-.209 \\
(.9)\end{array}$ \\
\hline Coloniallinkij & $\begin{array}{l}.005 \\
(.179)\end{array}$ & - & $\begin{array}{l}.281 \\
(.637)\end{array}$ \\
\hline Landlocked country & $\begin{array}{c}.067 \\
(.267)\end{array}$ & - & $\begin{array}{l}.544 \\
(.942)\end{array}$ \\
\hline AIFTAij & $\begin{array}{c}-.933 * * * \\
(.186)\end{array}$ & - & $\begin{array}{l}-.895 \\
(.684)\end{array}$ \\
\hline BIMSTECij & $\begin{array}{c}1.023^{* * *} \\
(.214)\end{array}$ & - & $\begin{array}{l}1.135 \\
(.784)\end{array}$ \\
\hline Constant & $\begin{array}{l}2.513 \\
(3.862)\end{array}$ & $\begin{array}{c}6.173^{* * *} \\
(1.028)\end{array}$ & $\begin{array}{c}4.774 \\
(6.226)\end{array}$ \\
\hline $\begin{array}{l}\text { R-squared } \\
\text { Jarque-Bera normality }\end{array}$ & $\begin{array}{l}0.661 \\
.2106\end{array}$ & 0.178 & 0.650 \\
\hline $\begin{array}{l}\text { test } \\
\text { Ho: normality } \\
\text { Ha: no normality }\end{array}$ & (p-value) & - & - \\
\hline White's test & 0.0000 & & \\
\hline $\begin{array}{l}\text { Ho: homoskedasticity } \\
\text { Ha: unrestricted } \\
\text { heteroskedasticity }\end{array}$ & (p-value) & - & - \\
\hline $\begin{array}{l}\text { Variance inflation } \\
\text { factor (VIF) } \\
\text { (Multicolliarity test) }\end{array}$ & $\begin{array}{c}1.921 \\
\text { (Mean VIF) }\end{array}$ & - & - \\
\hline $\begin{array}{l}\text { Hausman Specification } \\
\text { Test }\end{array}$ & - & $\begin{array}{c}0.2340 \\
(\mathrm{p}-\text { value })\end{array}$ & - \\
\hline
\end{tabular}

Sources: Authors' calculations based on collected data.

Robust standard errors are in parentheses.

${ }^{* * *} \mathrm{p}<.01, * * \mathrm{p}<.05, * \mathrm{p}<.1$ 
A Study of India's Trade Flows with the ASEAN: Gravity Model Analysis

\section{Conclusion}

This study attempted to produce conceptually compatible, econometrically plausible, and detailed estimates of international trade flow between all country pairings in the sample using panel data under gravity setting. We infer from our studies that AIFTA has a very trifling impact on bilateral trade between country pairs in the sample. Despite the fact that numerous FTAs have been negotiated, the benefits to exports remain minor. As a result, to reap the potential of preferential trade agreements, exporters should focus on expanding the number of commodities they export, as well as exercise greater caution when considering FTAs primarily on comparative advantages.

Export promotion measures should be used to advance trade with ASEAN's underdeveloped countries, such as Brunei Darussalam and Lao PDR because these countries have untapped potential. India can continue to increase its trade with the Philippines, Singapore and Thailand while keeping up the same pace with the rest of the ASEAN. The FTA's pledge has yet to be fulfilled, there is still room for both parties to explore their potential. To boost trade and deeper integration within the area, initiatives such as trade facilitation, improved production, export competitiveness and speedier conclusion of the bilateral discussion is needed. Negotiating bilateral FTAs with nations that have strong trade complementarities and margins of preference may help India in the long run. Increased compliance costs negate the benefits of margin of preference, therefore minimizing the compliance costs and administrative delays are crucial for increasing FTA usage.

The overarching conclusion of this study is that FTAs should be formed with two things in mind: mutually reciprocal conditions and a focus on products and services with maximum export potential. The government should spend more money on manpower development by imparting potential employees overseas to learn preferential usage techniques to produce specialists in each Free Trade Agreement.

\section{References}

Acharya, A. (2017). Studying Asian and Comparative regionalism through Amitav Acharya's work. International Relations of the Asia-Pacific, 15(3), 537-566.

Ahmad, S. (2010). India-ASEAN Free Trade Agreement: A Sectoral Analysis. SSRN 1698849.

Anderson, J. (1979). A Theoretical Foundation for the Gravity Equation. American Economic Review, 69, $106-116$.

Ando, M. \& Kimura, F. (2005). The gravity equation in international trade in service. International Review of Economics \& Finance, 14(3), 317-348.

ASEAN. (2012). ASE AN-India Free Trade Area. Retrieved from https://www.aseanbriefing.com/news/aseanindia-free-trade-area-part-i-introduction/

Bell, et al. (2018). Business research methods. Oxford university press.

Bergstand, J. (1985). The Gravity Equation in International Trade: Some Microeconomic Foundations and Empirical Evidence. The Review of Economics and Statistics, 67, 474-481.

Bhagwati, J. (2003). Going Alone: The Case for Relaxed Reciprocity in Freeing Trade. MIT Press.

Bhagwati, J. (2008). Termites in the Trading System. Oxford.

Bhattacharya, R. \& Banerjee, T. (2006). Does the Gravity Model Explain India Direction of Trade? A Panel Data Approach. International Economics, W.P. No. 2006-09-01. 
Bhattacharyya R., \& Mandal, A. (2010). Estimating the Impact of the Indo-ASEAN Free Trade Agreement on India's Balance of Trade. Journal of Global Analysis, 1(1), 7-25.

Bruderl, J. (2005). Panel Data Analysis. University of Mannheim. Retrieved from http://www.maktab-sms.ir/ Uploads/Ebooks/d3b706ac-a6fc-41d0-ab02-107c05c66ea0.pdf

Brülhart, M., \& Kelly, M. J. (1999). Ireland's trading potential with central and eastern European countries: A gravity study. Economic and Social Review, 30, 159-174.

CEPII-Database. (2021). Retrieved from http://www.cepii.fr/cepii/en/bdd_modele/bdd.asp

Chan, S. (2005). Does the Gravity Model Explain South Korea's Trade Flows? Japanese Economic Review, 56(4), 417-430.

De, P., \& Majumdar, M. (2014). Developing Cross-Border Production Networks between North Eastern Region of India, Bangladesh and Myanmar: A Preliminary Assessment. RIS, New Delhi.

Dinakaran, K. A. (2020). Export and Imports Stagnation in India During Covid-19 A Review. GIS Business, 15 , 1158-1177.

Drucker, M. (2003). Testing for serial correlation in linear panel-data models. The Stata Journal, 3(2), 168-177.

Egger, P., \& Pfaffermayr, M. (2005). The Determinants of Intra firm Trade: In Search for Export-Import Magnification Effects. Review of World Economy, 141(4), 648-669.

Endoh, M. (1999). Trade creation and trade diversion in the EEC, the and the CMEA: 1960-1994. Applied Economics, 31(2), 207-216.

Francis, S. (2011). A sectoral impact analysis of the ASEAN-India Free Trade Agreement. Economic \& Political Weekly, 46(2).

Frankel, J. (1997). Regional Trading Blocs in the World Economic System. Peterson Institute for International Economics, Washington DC.

Gomez E., \& Baleix, J. (2012). EMU impact of on third countries' exports: a gravity approach. The Papers 10/26, University of Granada.

Gul, N., \& Yasin, H. (2010). The trade potential of Pakistan: An application of the gravity model. The Lahore Journal of Economics, 16(1), 23-62.

Hummels, D. (2007). Transportation Costs and International Trade in the Second Era of Globalization. Journal of Economic Perspectives, 21(3), 131-154.

IMF. (2021). Retrieved from https:/ /www.imf.org/en/Publications/WEO/weo-database/2021/April.

Kapur, Y. (2021). India-ASEAN Trade and Investment Prospects. India Briefing.

Kimura, F. (2005). International Review of Economics \& Finance, 14(3), 317-348.

Krueger, A., \& Bhagwati J. (1995). The Dangerous Drift to Preferential Trade Agreements. AEI Press.

Limao, N. (2006). Preferential Trade Agreements as Stumbling Blocks for Multilateral Trade Liberalization: Evidence for the United States. American Economic Review, 96(3), 896-914.

Martiìnez-Zarzoso et al. (2009). Does German development aid promote German exports? German Economic Review, 10(3), 317-338.

Matyas, L. (1997). Proper Econometric Specification of the Gravity Model. The World Economy, Wiley Blackewell, 20(3), 363-368.

Nag, B., \& Sikdar, C. (2011). Impact of India-ASEAN Free Trade Agreement: A Cross-Country Analysis using applied general equilibrium modelling. Asia-Pacific Research and Training Network on Trade Working Paper(107). 
Ozdeser, H., \& Ertac, D. (2010). Turkey's Trade potential with eurozone countries: A Gravity Study. European Journal of Scientific Research, 43(1), 15-23.

Pal, P. \& Dasgupta, M. (2009). The ASEAN-India free trade agreement: An assessment, Economic and Political Weekly, 44(38).

Panagariya, A. (2004). India's Trade Reform: Progress, Impact and Future Strategy. International Trade 0403004, University Library of Munich, Germany.

Panagariya, A., \& Bhagwati, J. (2013). Why Growth Matters: How Economic Growth in India Reduces Poverty and the Lessons for Other Developing Countries.

Rahman, M. (2003). A Panel Data Analysis of Bangladesh's Trade: The Gravity Model Approach.

Rose, A. (2004). Do We Really Know that the WTO Increases Trade? American Economic Review, 94, 98-114.

Routray, B. (2011). India-Myanmar Relations: Triumph of Pragmatism. Jindal Journal of International Affairs, 1(1), $301-21$.

Shin, Y., \& Serlenga, L. (2007). Gravity Models of Intra-EU Trade: Application of the CCEP-HT Estimation in Heterogeneous Panels with Unobserved Common Time-Specific Factors. Journal of Applied Econometrics, 22(2), 361-381.

Tewari, R. \& Das, S. (2010). India-ASEAN Free Trade Agreement and Development of North East: Prospects and Challenges. UNCTAD.

Tinbergen, J. (1962). Shaping the World Economy: Suggestions for an International Economic Policy, 46, 271273.

Veeramani, C., \& Saini, G. (2010). Impact of ASEAN-India FTA on India's Plantation Commodities: A Simulation Analysis. Indira Gandhi Institute of Development Research, Mumbai, Working Papers 2010-04.

Viner, J. (1950). The Customs Union Issue. Carnegie Endowment for International Peace.

World Economic Outlook. (2021). IMF.

Yotov, et al. (2016). An Advanced Guide to Trade Policy Analysis: The Structural Gravity Model. World Trade Organization.

Zwinkels, R., \& Beugelsdijk, S. (2010). Gravity Equations: Workhorse or Trojan Horse in Explaining Trade and FDI Patterns Across Time and Space? 19(1), 102-115. 
Saurabh Kumar Bharti and Syeedun Nisa

\begin{tabular}{|c|c|c|c|c|c|}
\hline \multicolumn{6}{|c|}{ Appendix 1: Description of Statistics } \\
\hline Variables & Obs. & Mean & Std. Dev. & Min. & Max. \\
\hline Years & 260 & 2015 & 2.878 & 2011 & 2020 \\
\hline Exports & 260 & 7777.968 & 13876.012 & .182 & 77023.16 \\
\hline Imports & 260 & 4088.952 & 5336.634 & 15.504 & 28626.858 \\
\hline TotalTradewithIndia & 260 & 11866.919 & 18116.801 & 31.375 & 95871.051 \\
\hline LnTRADEijt & 260 & 8.199 & 1.8 & 3.446 & 11.471 \\
\hline DistanceKM & 260 & 2986.577 & 1399.447 & 683 & 5847 \\
\hline LnDISTANCEij & 260 & 7.867 & .562 & 6.526 & 8.674 \\
\hline GDPIndia & 260 & 7570.031 & 1275.77 & 5618.382 & 9562.013 \\
\hline LnGDPit & 260 & 8.918 & .171 & 8.634 & 9.166 \\
\hline GDPPartner & 260 & 1458.754 & 3700.031 & 4.688 & 24142.83 \\
\hline LnGDPjt & 260 & 5.729 & 1.871 & 1.545 & 10.092 \\
\hline CommonBorderij & 260 & .231 & .422 & 0 & 1 \\
\hline CommonLanguageij & 260 & .115 & .32 & 0 & 1 \\
\hline Coloniallinkij & 260 & .654 & .477 & 0 & 1 \\
\hline Landlockedcountry & 260 & .154 & .361 & 0 & 1 \\
\hline AIFTAij & 260 & .385 & .487 & 0 & 1 \\
\hline BIMSTECij & 260 & .231 & .422 & 0 & 1 \\
\hline
\end{tabular}

Source: Authors' Calculation.

Appendix 2: Countries Included in the Gravity Model Sample

\begin{tabular}{llll}
\hline AIFTA & BIMSTEC & GCC & OtherCountries \\
\hline Vietnam & Bangladesh & Bahrain & Japan \\
Thailand & Bhutan & Kuwait & Korea Rep. \\
Singapore & Nepal & Oman & China \\
Philippines & Sri Lanka & Qatar & Pakistan \\
Myanmar & & Saudi Arabia & Afghanistan \\
Malaysia & & United Arab Emirates & Maldives \\
Lao PDR & & \\
Indonesia & & \\
Brunei Darussalam & & & \\
Cambodia & & \\
India & & & \\
\hline
\end{tabular}

Source: Authors' Selection. 